\title{
Interstitial lung disease in gefitinib-treated Japanese patients with non-small cell lung cancer - a retrospective analysis: JMTO LC03-02 Masatsugu Nakagawa* ${ }^{* 1,2,5}$, Tsutomu Nishimura ${ }^{\dagger 1,5}$, Satoshi Teramukai ${ }^{1,5}$, Harue Tada1,5, Fumihiro Tanaka ${ }^{3,5}$, Kazuhiro Yanagihara ${ }^{4,5}$, Kiyoyuki Furuse ${ }^{5}$, Hiromi Wada ${ }^{2,5}$ and Masanori Fukushima1,5,6
}

\author{
Address: ${ }^{1}$ Department of Clinical Trial Design and Management, Translational Research Center, Kyoto University Hospital, Kyoto, Japan, \\ ${ }^{2}$ Department of Thoracic Surgery, Kyoto University, Kyoto, Japan, ${ }^{3}$ Department of Thoracic Surgery, Hyogo College of Medicine, Nishinomiya, \\ Japan, ${ }^{4}$ Department of Translational Clinical Oncology, Kyoto University, Kyoto, Japan, ${ }^{5}$ The Japan Multinational Trial Organization, Kyoto, Japan \\ and ${ }^{6}$ Translational Research Informatics Center, Kobe, Japan \\ Email: Masatsugu Nakagawa* - noooooi@kuhp.kyoto-u.ac.jp; Tsutomu Nishimura - t246ra@kuhp.kyoto-u.ac.jp; \\ Satoshi Teramukai - steramu@kuhp.kyoto-u.ac.jp; Harue Tada - haru.ta@kuhp.kyoto-u.ac.jp; Fumihiro Tanaka - ftanaka@hyo-med.ac.jp; \\ Kazuhiro Yanagihara - kazuhiro@kuhp.kyoto-u.ac.jp; Kiyoyuki Furuse - furusek@osaka.email.ne.jp; Hiromi Wada - wadah@kuhp.kyoto-u.ac.jp; \\ Masanori Fukushima - mfukushi@kuhp.kyoto-u.ac.jp \\ * Corresponding author †Equal contributors
}

Published: 5 August 2009

BMC Research Notes 2009, 2:157 doi:10.1186/1756-0500-2-157

This article is available from: http://www.biomedcentral.com/1756-0500/2/157

(C) 2009 Nakagawa et al; licensee BioMed Central Ltd.

This is an Open Access article distributed under the terms of the Creative Commons Attribution License (http://creativecommons.org/licenses/by/2.0), which permits unrestricted use, distribution, and reproduction in any medium, provided the original work is properly cited.
Received: 10 February 2009

Accepted: 5 August 2009

\begin{abstract}
Background: In Japan, high incidences of interstitial lung disease (ILD) and ILD-related deaths have been reported among gefitinib-treated patients with non-small cell lung cancer (NSCLC). We investigated the efficacy of gefitinib, the incidence of ILD and risk factors for ILD in these patients.

Findings: We obtained patient data retrospectively using questionnaires sent to 22 institutions. We asked for demographic and clinical data on NSCLC patients for whom gefitinib treatment had begun between July 2002 and February 2003. Data from a total of 526 patients were analyzed. The patient characteristics were as follows: $64 \%$ male, $69 \%$ with adenocarcinoma, $61 \%$ with a performance score of $0-1$, and $5 \%$ with concurrent interstitial pneumonitis. The objective response proportion was $80 / 439$ (I8.2\%; $95 \% \mathrm{Cl}$ : 14.7-22.0). ILD developed in 17 patients (3.2\%; $95 \% \mathrm{Cl}$ I.9$5.1 \%)$, of whom 7 died. According to multivariate analysis, female sex, history of prior chemotherapy, low absolute neutrophil count before gefitinib treatment, and adenocarcinoma histology were associated with response to gefitinib treatment. None of the factors we evaluated were associated with the development of ILD.
\end{abstract}

Conclusion: The results of this study are consistent with previously published values for treatment response proportions and incidence of ILD during gefitinib treatment in Japanese patients. Future studies should be aimed at identifying factors indicating that a patient has a high probability of receiving benefit from gefitinib and a low risk of developing ILD.

\section{Background}

In most industrialized countries, non-small cell lung cancer (NSCLC) is the leading cause of death from cancer [1].
At the time of diagnosis, the majority of NSCLC patients have advanced disease that is not amenable to curative approaches, so NSCLC is associated with a poor progno- 
sis. Platinum-based chemotherapy provides a survival benefit of limited duration [2], and combinations of newer active agents (such as gemcitabine and paclitaxel) with platinum have produced further improvement in survival $[3,4]$. Docetaxel has been approved as a secondline chemotherapy agent on the basis of randomized trials involving patients in whom first-line chemotherapy was unsuccessful, but the objective response proportions to docetaxel are only $5-10 \%$, and treatment is associated with only a modest survival benefit $[5,6]$.

Gefitinib is an orally active selective inhibitor of the epidermal growth factor receptor (EGFR) tyrosine kinase and has been found to have antitumor activity in patients with advanced NSCLC who have undergone prior treatment. According to several multicenter phase I trials [7-9], diarrhea, skin rashes, and nausea are common adverse events associated with gefitinib treatment, but most of these adverse events are mild. Based on the results of two large-scale multicenter phase II studies (IDEAL 1 and 2; Iressa Dose Evaluation in Advanced Lung Cancer) [10,11], in July 2002 gefitinib was approved in Japan for the treatment of inoperable or recurrent NSCLC. However, since approval, a number of deaths due to gefitinib-induced interstitial lung disease (ILD) have been reported [12,13], and the high incidences of ILD and associated mortality have become a matter of great concern in Japan. Risk-benefit assessments have become critical in the use of gefitinib. We report here the results of a retrospective study conducted by the Japan Multinational Trial Organization (JMTO: http://www.jmto.org/) to investigate the response proportion, factors predicting response, and the incidence of and risk factors for ILD in gefitinib-treated NSCLC patients.

\section{Methods}

Patients with histologically or cytologically confirmed NSCLC of any clinical or pathological stage, who began taking gefitinib between July 2002 and February 2003, were eligible for inclusion in the study. We obtained patient data using questionnaires sent to 22 institutions, and retrospectively analyzed the information provided in the returned questionnaires, including laboratory findings. The study protocol (JMTO LC03-02) was approved by the ethics committees of JMTO and the participating institutions.

Baseline assessments included age, sex, histological type of NSCLC, clinical or pathological stage of cancer at diagnosis (using the current TNM classification system [14]), Eastern Cooperative Oncology Group (ECOG) performance status (PS), history of smoking before starting gefitinib treatment, medical history (including prior anticancer therapy), concurrent pulmonary disease (e.g. interstitial pneumonitis or pulmonary emphysema), and laboratory findings (complete blood cell count, blood biochemistry, arterial blood gas analysis data). Diagnoses of concurrent pulmonary disease were made by each institution on a clinical basis.

The endpoints of this study were response to gefitinib treatment or occurrence of a serious adverse event during gefitinib treatment or death due to the serious adverse event. Adverse events were evaluated using the National Cancer Institute Common Toxicity Criteria (NCI-CTC), version 2.0, and a serious adverse event was defined as being an NCI-CTC grade 4 adverse event, or any experience that resulted in death, was life-threatening, required inpatient hospitalization or prolongation of existing hospitalization, resulted in persistent or significant disability/ incapacity, or caused a congenital anomaly/birth defect, according to the definition published by the International Conference on Harmonisation of Technical Requirements for Registration of Pharmaceuticals for Human Use [15]. In this study, ILD was assumed to be interstitial pneumonitis as diagnosed by each institution on a clinical basis.

If patients had measurable disease, tumor response was assessed on the basis of medical records, and if not mentioned in the medical records, the Response Evaluation Criteria in Solid Tumors (RECIST) [16] or the World Health Organization (WHO) criteria [17] were used for assessment. The objective response was calculated as the proportion of patients with a complete or partial response.

Associations between serious adverse events or objective response and patient characteristics were assessed using a logistic regression model. Odds ratios (ORs) and 95\% confidence intervals (CIs) were estimated using univariate analysis, and a backward elimination procedure was used to identify significant predictors in the multivariate analysis. Because of the comparability of the ORs, the units used to measure absolute neutrophil count and lactate dehydrogenase (LDH) level were Log transformed. Predictive response probabilities were estimated based on a final multivariate logistic regression model for evaluating associations between response and ILD occurrence. All statistical analyses were carried out using SAS version 8.02 (SAS Institute, Cary NC, USA).

\section{Results}

\section{Patient characteristics}

A total of 536 patients were enrolled in this study, of which 526 patients were eligible for analysis (10 patients were excluded from analysis because they began taking gefitinib before July 2002 or after February 2003). The patient characteristics and laboratory findings are summarized in Table 1. 
Table I: Patient characteristics $(n=526)$.

\begin{tabular}{|c|c|c|c|}
\hline Characteristic & No. patients & $\%$ patients & Mean $( \pm S D)$ \\
\hline Age (years) & 526 & & $\begin{array}{c}66.2 \\
\text { (range 27-9I) }\end{array}$ \\
\hline \multicolumn{4}{|l|}{ Sex } \\
\hline Male & 336 & 64 & \\
\hline Female & 190 & 36 & \\
\hline \multicolumn{4}{|l|}{ Histological type } \\
\hline Adenocarcinoma & 360 & 69 & \\
\hline Squamous cell carcinoma & 123 & 23 & \\
\hline Other & 43 & 8 & \\
\hline \multicolumn{4}{|l|}{ History of smoking } \\
\hline No & 170 & 32 & \\
\hline Yes & 319 & 61 & \\
\hline Unknown & 37 & 7 & \\
\hline \multicolumn{4}{|l|}{ ECOG performance status } \\
\hline $0-1$ & 321 & 61 & \\
\hline $2-4$ & 191 & 36 & \\
\hline Unknown & 14 & 3 & \\
\hline \multicolumn{4}{|c|}{ Concurrent interstitial pneumonitis } \\
\hline No & 500 & 95 & \\
\hline Yes & 26 & 5 & \\
\hline \multicolumn{4}{|c|}{ Concurrent pulmonary emphysema } \\
\hline No & 447 & 85 & \\
\hline Yes & 77 & 15 & \\
\hline Unknown & 2 & $<1$ & \\
\hline \multicolumn{4}{|c|}{ History of pulmonary tuberculosis } \\
\hline No & 491 & 93 & \\
\hline Yes & 34 & 7 & \\
\hline Unknown & 1 & $<1$ & \\
\hline \multicolumn{4}{|l|}{ Prior surgery for lung cancer } \\
\hline No & 337 & 64 & \\
\hline Yes & 189 & 36 & \\
\hline \multicolumn{4}{|c|}{ Prior chemotherapy for lung cancer } \\
\hline No & 115 & 22 & \\
\hline Yes & 411 & 78 & \\
\hline \multicolumn{4}{|c|}{ Prior thoracic radiotherapy for primary lung cancer } \\
\hline No & 330 & 63 & \\
\hline Yes & 194 & 37 & \\
\hline Unknown & 2 & $<1$ & \\
\hline \multicolumn{4}{|c|}{ Concurrent chemotherapy with agent other than gefitinib } \\
\hline No & 485 & 92 & \\
\hline Yes & 41 & 8 & \\
\hline \multicolumn{4}{|c|}{ Thoracic radiotherapy concurrent with or after gefitinib treatment } \\
\hline No & 478 & 91 & \\
\hline Yes & 48 & 9 & \\
\hline
\end{tabular}


Table I: Patient characteristics $(\mathrm{n}=526)$. (Continued)

\begin{tabular}{lcc}
\hline Absolute neutrophil count $(/ \mu \mathrm{L})$ & 485 & $4786( \pm 3331)$ \\
Eosinophil count $(/ \mu \mathrm{L})$ & 483 & $163( \pm 181)$ \\
Creatinine level $(\mathrm{mg} / \mathrm{dL})$ & 496 & $0.77( \pm 0.44)$ \\
Platelet count $\left(\times / 0^{4} / \mu \mathrm{L}\right)$ & 515 & $25.8( \pm 10.3)$ \\
Albumin level $(\mathrm{g} / \mathrm{dL})$ & 424 & $3.67( \pm 0.58)$ \\
Aspartate aminotransferase level $(\mathrm{IU} / \mathrm{L})$ & 487 & $25( \pm 20)$ \\
Alanine aminotransferase level $(\mathrm{IU} / \mathrm{L})$ & 515 & $23( \pm 25)$ \\
Lactate dehydrogenase level $(\mathrm{IU} / \mathrm{L})$ & 495 & $279( \pm 318)$
\end{tabular}

The mean patient age was 66.2 years (range 27-91 years). A total of 336 patients (64\%) were male, 360 patients (69\%) had adenocarcinoma, and 319 patients (61\%) were current or former smokers. In 26 patients $(4.9 \%)$, NSCLC was accompanied by concurrent interstitial pneumonitis. Gefitinib was given as a first-line chemotherapeutic agent in 115 patients.

With respect to the laboratory findings before gefitinib treatment, absolute neutrophil count, aspartate aminotransferase (AST) level, alanine aminotransferase (ALT) level, and LDH level were reported for 485, 487, 515, and 495 patients, respectively (Table 1 ).

\section{Response to treatment}

For 439 patients (83\%), tumor response was reported and evaluable. Complete and partial responses were observed for 7 and 73 patients, respectively. The objective response proportion was $80 / 439$ (18.2\%; 95\% CI: 14.7-22.0), and the disease control proportion, which was the objective response plus the proportion of patients with stable disease, was $237 / 439$ (54.0\%).

\section{Factors predicting tumor response}

The association between tumor response and various clinical factors was assessed using logistic regression. In the univariate analysis (Table 2), sex, histological type, history of smoking, concurrent pulmonary emphysema, history of prior chemotherapy, high absolute neutrophil count, low LDH level, and high serum albumin level were found to be associated with tumor response $(\mathrm{p}<0.1)$. In the multivariate analysis (Table 3), female sex (OR: 4.35; 95\% CI: 2.40-7.90; $\mathrm{p}<0.001)$, history of prior chemotherapy (OR: 0.34; 95\% CI: 0.18-0.65; p = 0.001), high absolute neutrophil count (OR: 0.85 per $1000 / \mu \mathrm{L} ; 95 \%$ CI: $0.75-0.93 ; \mathrm{p}=0.017)$, and adenocarcinoma histology (OR: 2.35; 95\% CI: 1.03-5.35; p = 0.043) were statistically significantly associated with tumor response.

\section{ILD and other serious adverse events}

Serious adverse events occurred during gefitinib treatment in 66 of 526 patients. ILD developed in 17 patients $(3.2 \%$; 95\% CI: $1.9 \%-5.1 \%), 7$ (41\%) of whom died during treatment. Hepatic dysfunction occurred in seven patients, one of whom died during treatment. Other seri- ous adverse events included skin rash, diarrhea, aspiration pneumonia, perforative peritonitis, acute enteritis, convulsion, epilepsy, cancerous pain.

\section{Analysis of factors affecting ILD}

The association between ILD and various clinical factors was evaluated using logistic regression. In the univariate analysis, none of the factors we evaluated were found to be associated with the development of ILD, including sex, history of smoking, concurrent interstitial pneumonitis, history of prior chemotherapy, or poor ECOG PS.

\section{Analysis of the relation between response and ILD}

We assessed the association between response and ILD occurrence. When the predictive probability of a response was estimated based on related factors (sex, history of prior chemotherapy, absolute neutrophil count, and histology) for each patient, no association between response probability and occurrence of ILD was detected (chisquare test, $\mathrm{p}=0.379$ ) (Figure 1 ). When the probability of a response was $0-0.10$, the incidence of ILD was $3.8 \%$ (8/ $211,95 \% \mathrm{CI}: 1.7 \%-7.3 \%$ ), and when the probability was above 0.30 , the incidence was $5.3 \%(6 / 114,95 \% \mathrm{CI}$ : $2.0 \%-11.1 \%)$.

\section{Discussion}

In the present study, the gefitinib response proportion was $18.2 \%$, which is similar to values determined in other studies and clinical trials $[10,18,19]$. The response proportion among patients with a history of prior chemotherapy was $15.5 \%$, which was somewhat higher than values observed in clinical trials of docetaxel chemotherapy for previously treated NSCLC patients $(10.8 \%$ and $7.1 \%)$ $[5,6]$.

In this study, female sex, no history of prior chemotherapy, low absolute neutrophil count, and adenocarcinoma histology were associated with tumor response. There have been a number of prior studies of the predictive factors for tumor response in gefitinib-treated NSCLC patients in Japan [20-24], and results of these are summarized in Table 4. Although female sex and adenocarcinoma histology have also been found to be associated with tumor response in other studies, absence of prior chemotherapy and low absolute neutrophil have not. The 
Table 2: Predictive factors for tumor response and risk factors associated with ILD (univariate analysis)

\begin{tabular}{|c|c|c|c|c|c|c|}
\hline Factor & $\begin{array}{c}\text { Response } \\
\text { proportion (\%) }\end{array}$ & $\begin{array}{l}\text { Odds } \\
\text { ratio }(95 \% \mathrm{Cl})\end{array}$ & $\mathrm{P}$-value & $\begin{array}{l}\text { Incidence of } \\
\text { ILD (\%) }\end{array}$ & $\begin{array}{l}\text { Odds ratio } \\
(95 \% \mathrm{Cl})\end{array}$ & $\mathrm{p}$-value \\
\hline Age & - & $1.01(0.98-1.03)$ & 0.644 & & $1.00(0.95-1.04)$ & 0.823 \\
\hline \multicolumn{7}{|l|}{ Sex } \\
\hline Male & 8.4 & I & - & 2.7 & 1 & - \\
\hline Female & 34.3 & $5.68(3.33-9.69)$ & $<0.001$ & 4.2 & $1.60(0.6 \mid-4.21)$ & 0.344 \\
\hline \multicolumn{7}{|l|}{ Histological type } \\
\hline Non-adenocarcinoma & 6.0 & I & - & 3.6 & I & - \\
\hline Adenocarcinoma & 23.6 & $4.86(2.27-10.42)$ & $<0.001$ & 3.1 & $0.84(0.31-2.33)$ & 0.737 \\
\hline \multicolumn{7}{|l|}{ History of smoking } \\
\hline Yes & 10.5 & 1 & - & 3.1 & 1 & - \\
\hline No & 33.8 & $4.33(2.57-7.29)$ & $<0.001$ & 4.1 & $1.33(0.50-3.57)$ & 0.573 \\
\hline \multicolumn{7}{|l|}{ ECOG performance status } \\
\hline $2-4$ & 14.4 & 1 & - & 2.6 & I & - \\
\hline $0-1$ & 20.3 & $1.51(0.89-2.59)$ & 0.129 & 3.6 & $1.39(0.48-4.00)$ & 0.549 \\
\hline \multicolumn{7}{|l|}{ Concurrent interstitial pneumonitis } \\
\hline No & 18.9 & I & - & 3.2 & I & \\
\hline Yes & 5.0 & $0.23(0.03-1.72)$ & 0.151 & 3.8 & $1.21(0.15-9.49)$ & \\
\hline \multicolumn{7}{|l|}{ Concurrent pulmonary emphysema } \\
\hline No & 19.9 & 1 & - & 3.1 & 1 & \\
\hline Yes & 7.1 & $0.31(0.11-0.88)$ & 0.028 & 3.9 & $1.25(0.35-4.47)$ & \\
\hline \multicolumn{7}{|l|}{ Prior surgery } \\
\hline No & 16.0 & 1 & - & 3.6 & 1 & - \\
\hline Yes & 22.2 & $1.49(0.91-2.44)$ & 0.111 & 2.6 & $0.74(0.26-2.12)$ & 0.571 \\
\hline \multicolumn{7}{|l|}{ Prior chemotherapy } \\
\hline No & 28.6 & 1 & - & 2.6 & 1 & - \\
\hline Yes & 15.5 & $0.46(0.27-0.79)$ & 0.005 & 3.4 & $1.32(0.37-4.66)$ & 0.670 \\
\hline \multicolumn{7}{|l|}{ Prior thoracic radiotherapy } \\
\hline No & 19.3 & 1 & - & 3.9 & I & - \\
\hline Yes & 16.6 & $0.83(0.50-1.38)$ & 0.468 & 2.1 & $0.51(0.17-1.60)$ & 0.250 \\
\hline \multicolumn{7}{|l|}{$\begin{array}{l}\text { Concurrent chemotherapy with } \\
\text { agent other than gefitinib }\end{array}$} \\
\hline No & 17.3 & I & - & 3.5 & - & - \\
\hline Yes & 28.6 & $1.91(0.88-4.15)$ & 0.103 & 0 & - & - \\
\hline \multicolumn{7}{|l|}{$\begin{array}{l}\text { Thoracic radiotherapy concurrent } \\
\text { with or after gefitinib treatment }\end{array}$} \\
\hline No & 18.8 & I & - & 3.1 & 1 & - \\
\hline Yes & 12.8 & $0.64(0.24-1.69)$ & 0.364 & 4.2 & $1.34(0.30-6.05)$ & 0.702 \\
\hline Absolute neutrophil count $*$ & - & $0.84(0.75-0.95)$ & 0.004 & - & $0.96(0.81-1.14)$ & 0.609 \\
\hline Aspartate aminotransferase level $* *$ & - & $1.00(0.99-1.01)$ & 0.967 & - & $0.99(0.95-1.03)$ & 0.635 \\
\hline Lactate dehydrogenase level $* * *$ & - & $0.82(0.65-1.03)$ & 0.085 & - & $0.95(0.71-1.27)$ & 0.724 \\
\hline Albumin level $* * * *$ & - & $1.54(0.97-2.44)$ & 0.067 & - & $1.65(0.67-4.07)$ & 0.278 \\
\hline
\end{tabular}

* per: 1000/ $\mathrm{LL}$ **: per IU/L ***: per $100 \mathrm{IU} / \mathrm{L} * * * *$ : per g/dL 
Table 3: Factors predicting tumor response (multivariate analysis)

\begin{tabular}{|c|c|c|c|}
\hline Factor & No. patients & Odds ratio $(95 \% \mathrm{Cl})$ & $\mathrm{P}$-value \\
\hline \multicolumn{4}{|l|}{ Sex } \\
\hline Male & 256 & 1 & - \\
\hline Female & 152 & $4.35(2.40-7.90)$ & $<0.001$ \\
\hline \multicolumn{4}{|l|}{ Prior chemotherapy } \\
\hline No & 82 & I & - \\
\hline Yes & 326 & $0.34(0.18-0.65)$ & 0.001 \\
\hline Absolute neutrophil count & 408 & $0.85(0.75-0.93)^{*}$ & 0.017 \\
\hline \multicolumn{4}{|l|}{ Histological type } \\
\hline Non-adenocarcinoma & 127 & 1 & - \\
\hline Adenocarcinoma & 281 & $2.35(1.03-5.35)$ & 0.043 \\
\hline
\end{tabular}

Valuables with $\mathrm{p}<0.05$ were selected using a backward elimination procedure.

*per 1000/ $\mu \mathrm{L}$.

reason for the differences between the previous and the present results is unknown, but prior chemotherapy treatment may adversely affect tumor response to gefitinib.

The incidence of ILD in this study was 3.2\%, which is similar to the values determined in other studies (3.5-5.8\%) (Table 4). Determining the incidence of anti-EGFR therapy-related ILD in NSCLC is complicated by many factors, including the underlying neoplastic disease, adverse events caused by other chemotherapy agents, oxygen treatment, radiation therapy, and opportunistic infections. In a study conducted by the West Japan Thoracic Oncology Group (WJTOG) [23], the incidence of ILD in gefitinib-treated NSCLC patients was found to be $3.5 \%$. In that study, ILD was defined as diffuse interstitial changes or ground-glass appearance, and the diagnosis was confirmed on the basis of radiological findings and clinical data by a central review committee comprising chest radiologists, chest physicians, and oncologists. In the present study, ILD was defined as a diagnosis of interstitial pneu-

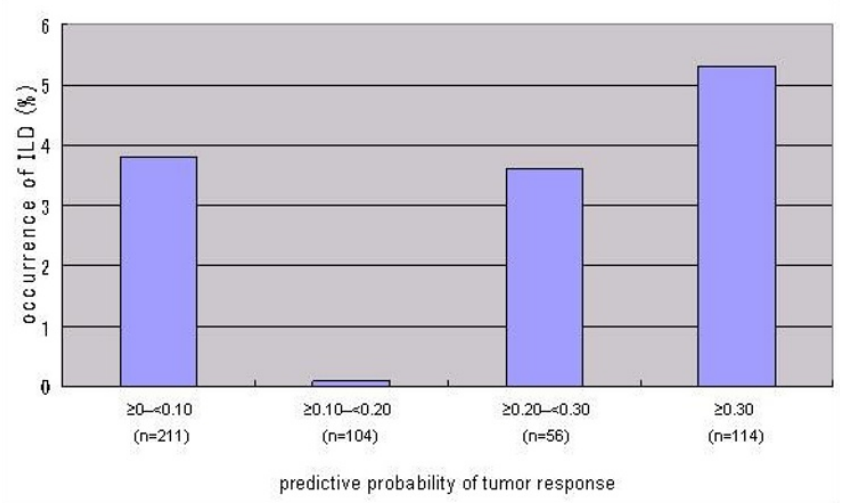

\section{Figure I}

Relationship between predictive probability of tumor response and ILD. monitis during gefitinib treatment, as diagnosed by each institution on a clinical basis. A central review committee was not involved. Despite this methodological difference, the incidence of ILD in the present study population was similar to the value found in the WJTOG study.

Risk factors for ILD have been identified in a number of studies of Japanese gefitinib-treated NSCLC patients (Table 4). In the present study, we also attempted to identify risk factors for ILD in gefitinib-treated NSCLC patients, but unlike the previous studies, none of the factors we evaluated were found to be significant, including sex, history of smoking, concurrent interstitial pneumonitis, history of prior chemotherapy, and poor PS. We cannot explain why this might be, but other risk factors that we did not investigate may possibly be associated with ILD.

In the interests of patient welfare, we need criteria by which patients with factors predicting tumor response or survival benefit and without factors predisposing to ILD can be selected. In the WJTOG study it was concluded that patient selection on the basis of female sex and the absence of a history of smoking will increase the clinical benefit of treatment with gefitinib and reduce the risk of ILD [23]. In the present study, we found no factors that clearly increase the benefit or decrease the risk. We did not find an association between the predictive response probability and the occurrence of ILD. The mechanism by which gefitinib might cause ILD is unclear, but that may be because the site at which gefitinib acts is different from that at which ILD manifests. Because of the considerable risk to patients, further studies investigating risk factors are warranted. The limitations of the present study were the retrospective design, the relatively small number of patients, and the conduction of the study using questionnaire, but the results of present study were similar to those of the previous reports. 
Table 4: Risk factors for ILD associated with gefitinib use and predictive factors for tumor response in Japanese patients as determined by studies in the literature

\begin{tabular}{|c|c|c|c|c|c|c|}
\hline Reference & No. patients & $\begin{array}{c}\text { No. cases ILD } \\
(\%)\end{array}$ & $\begin{array}{l}\text { No. ILD deaths } \\
(\%)\end{array}$ & $\begin{array}{l}\text { Risk factors for } \\
\text { ILD }\end{array}$ & $\begin{array}{c}\text { Response } \\
\text { Proportion (\%) }\end{array}$ & $\begin{array}{l}\text { Predictive factors } \\
\text { for tumor } \\
\text { response }\end{array}$ \\
\hline $\begin{array}{c}\text { National Cancer } \\
\text { Center, Japan (2004) } \\
{[20]}\end{array}$ & 112 & $\begin{array}{c}6 \\
(5.4)\end{array}$ & $\begin{array}{c}4 \\
(3.6)\end{array}$ & $\begin{array}{l}\text {-Pre-existing } \\
\text { pulmonary fibrosis }\end{array}$ & 33 & $\begin{array}{l}\text {-No history of } \\
\text { smoking } \\
\text {-No history of } \\
\text { thoracic radiotherapy }\end{array}$ \\
\hline $\begin{array}{l}\text { Okayama Lung } \\
\text { Cancer } \\
\text { Study Group } \\
(2005)[21]\end{array}$ & 330 & $\begin{array}{c}15 \\
(4.5)\end{array}$ & $\begin{array}{c}8 \\
(2.4)\end{array}$ & $\begin{array}{l}\text {-PS 2-4 } \\
\text {-Pre-existing } \\
\text { pulmonary fibrosis } \\
\text {-Prior thoracic } \\
\text { irradiation }\end{array}$ & 22 & Not investigated \\
\hline $\begin{array}{c}\text { AstraZeneca } \\
\text { (2004) [22] }\end{array}$ & 3322 & $\begin{array}{l}193 \\
(5.8)\end{array}$ & $\begin{array}{c}83 \\
(2.5)\end{array}$ & $\begin{array}{l}\text {-PS 2-4 } \\
\text {-History of smoking } \\
\text {-Coexisting IP } \\
\text {-Prior } \\
\text { chemotherapy }\end{array}$ & 7.8 & Not investigated \\
\hline $\begin{array}{l}\text { West Japan Thoracic } \\
\text { Oncology Group } \\
\text { (2006) [23] }\end{array}$ & 1976 & $\begin{array}{c}70 \\
(3.5)\end{array}$ & $\begin{array}{c}31 \\
(1.6)\end{array}$ & $\begin{array}{l}\text {-History of smoking } \\
\text {-Male } \\
\text {-Coexisting IP }\end{array}$ & 17.6 & $\begin{array}{l}\text {-PS 0-I } \\
\text {-No history of } \\
\text { smoking } \\
\text {-Female } \\
\text {-Adenocarcinoma } \\
\text {-Metastatic disease }\end{array}$ \\
\hline $\begin{array}{c}\text { AstraZeneca } \\
\text { (2007) [24] }\end{array}$ & 1482 & $\begin{array}{c}59 \\
(4.0)\end{array}$ & $\begin{array}{c}\text { ILD-related } \\
\text { deaths } \\
\text { In patients with } \\
\text { ILD were } 31.6 \%\end{array}$ & $\begin{array}{l}\text {-PS 2-4 } \\
\text {-History of smoking } \\
\text {-Age >55 years } \\
\text {-Recent NSCLC } \\
\text { diagnosis, } \\
\text {-Reduced normal } \\
\text { lung on } \\
\text { computed } \\
\text { tomography scan } \\
\text {-Preexisting chronic } \\
\text { ILD } \\
\text {-Concurrent } \\
\text { cardiac disease }\end{array}$ & $\begin{array}{c}\text { Not } \\
\text { investigated }\end{array}$ & Not investigated \\
\hline Present study & 526 & $\begin{array}{c}17 \\
(3.2)\end{array}$ & $\begin{array}{c}7 \\
(1.3)\end{array}$ & $\begin{array}{l}\text { No factors found to } \\
\text { be significant }\end{array}$ & 18.2 & $\begin{array}{l}\text {-Female } \\
\text {-No previous } \\
\text { chemotherapy } \\
\text {-Low absolute } \\
\text { neutrophil count } \\
\text {-Adenocarcinoma }\end{array}$ \\
\hline
\end{tabular}

\section{Conclusion}

The results of this study are consistent with previously published values for treatment response proportions and incidence of ILD during gefitinib treatment. In the interests of patient welfare, ILD in gefitinib-treated NSCLC patients should be investigated further in large-scale prospective studies, in which patients should be selected on the basis of factors affecting ILD and predicting tumor response.

\section{Competing interests}

This study was supported by AstraZeneca.

\section{Authors' contributions}

MN participated in the design of the study, carried out the study, and drafted the manuscript. TN carried out data management and helped to draft the manuscript. ST participated in the design of the study and performed the statistical analysis. HT participated in the design of the study and carried out data management. FT participated in the design of the study and carried out the study. KY, KF and 
HW participated in the design of the study and carried out the study. MF conceived the study, participated in its design and coordination, and helped to draft the manuscript. All authors read and approved the final manuscript.

\section{Acknowledgements}

We thank Ms. Akiko Matsuyama, Mr. Naoki Eguchi, Ms. Yuka Fujii (Translational Research Center, Graduate School of Medicine, Kyoto University, Kyoto, Japan) for their assistance with data management.

Japan-Multinational Trial Organization (JMTO) conducted this study (JMTO LC03-04) with the cooperation of the following investigators: Fumihiro Tanaka, Tadashi Mio and Hiromi Wada, Kyoto University Hospital, Kyoto; Toshiki Hirata, Kishiwada City Hospital, Osaka; Yuki Teranishi, Haruhisa Kitano, Akihiro Aoyama, Miyuki Nagasawa and Toru Shindo, Tenri Hospital, Nara; Tetuhiro Shiota, Ako City Hosipital, Hyogo; Keisuke Tomii, Kobe JapanPost Hospital, Hyogo; Seisuke Niibayashi, Kyotominami Hospital, Kyoto; Tomoaki Matsuoka and Norihito Okumura, Kurashiki Central Hospital, Okayama; Fumitsugu Kojima, Nobuya Mino and Kazuya Matsumoto, Osaka Saiseikai Noe Hospital, Osaka; Kazumi Itoi, Hyogo Prefectural Amagasaki Hospital, Hyogo; Shiro Fujita Osaka Saiseikai Nakatsu Hospital, Osaka; Motonari Fukui, Kitano Hospital, Osaka; Yoshiro Kubo and Keijiro Kono, Osaka Red Cross Hospital, Osaka; Noritaka Isowa, Matsue Red Cross Hospital, Shimane; Mitsuhiro Ueda and Tatsuji Kato, Kokura Memorial Hospital, Fukuoka; Yasumichi Yamamoto and Hiroyasu Yokomise, 2nd Department of Surgery, Faculty of Medicine, Kagawa University, Kagawa; Hiroshi Fujii, Kobe Nishi City Hospital, Hyogo; Takashi Koba, Toshihiro Okamoto and Hiroshi Mizuno, Kansai Denryoku Hospital, Osaka; Tuyoshi Takahashi and Shinji Kosaka, Shimane Prefectural Central Hospital, Shimane; Hiromi Tomioka and Minoru Aoki, Nishi-Kobe Medical Center, Hyogo; Masaaki Kawahara, National Hospital Organization Kinki-chuo Chest Medical Center, Osaka; Yuichi Ando and Yasutsuna Sasaki, Department of Clinical Oncology, Saitama Medical School, Saitama.

\section{References}

I. Samet JM: Epidemiology of Lung Cancer New York, Marcel Dekker, Inc; 1994:I.

2. Non-small Cell Lung Cancer Collaborative Group: Chemotherapy in non-small cell lung cancer: a meta-analysis using updated data on individual patients from 52 randomised clinical trials. BM] 1995, 3 I I:899-909.

3. Bonomi P, Kim K, Fairclough D, Cella D, Kugler J, Rowinsky E, Jiroutek M, Johnson D: Comparison of survival and quality of life in advanced non-small-cell lung cancer patients treated with two dose levels of paclitaxel combined with cisplatin versus etoposide with cisplatin: results of an Eastern Cooperative Oncology Group trial. J Clin Oncol 2000, 18:623-63I.

4. Rudd RM, Gower NH, Spiro SG, Eisen TG, Harper PG, Littler JA, Hatton M, Johnson PW, Martin WM, Rankin EM, James LE, Gregory WM, Qian W, Lee SM: Gemcitabine plus carboplatin versus mitomycin, ifosfamide, and cisplatin in patients with stage IIIb or IV non-small-cell lung cancer: a phase III randomized study of the London Lung Cancer Group. J Clin Oncol 2005, 23:142-153

5. Fossella F, Pereira JR, von Pawel J, Pluzanska A, Gorbounova V, Kaukel E, Mattson KV, Ramlau R, Szczesna A, Fidias P, Millward M, Belani CP: Randomized phase III trial of docetaxel versus vinorelbine or ifosfamide in patients with advanced nonsmall-cell lung cancer previously treated with platinum-containing chemotherapy regimens. J Clin Oncol 2000, I 8:2354-2362

6. Shepherd FA, Dancey J, Ramlau R, Mattson K, Gralla R, O'Rourke M, Levitan N, Gressot L, Vincent M, Burkes R, Coughlin S, Kim Y, Berille $\mathrm{J}$ : Prospective randomized trial of docetaxel versus best supportive care in patients with non-small-cell lung cancer pre- viously treated with platinum-based chemotherapy. I Clin Oncol 2000, 18:2095-2103.

7. Baselga J, Rischin D, Ranson M, Calvert H, Raymond E, Kieback DG, Kaye SB, Gianni L, Harris A, Bjork T, Averbuch SD, Feyereislova A, Swaisland H, Rojo F, Albanell J: Phase I safety, pharmacokinetic, and pharmacodynamic trial of ZD a selective oral epidermal growth factor receptor tyrosine kinase inhibitor, in patients with five selected solid tumor types. J Clin Oncol 2002, 20:4292-4302.

8. Herbst RS, Maddox AM, Rothenberg ML, Small EJ, Rubin EH, Baselga J, Rojo F, Hong WK, Swaisland H, Averbuch SD, Ochs J, LoRusso PM: Selective oral epidermal growth factor receptor tyrosine kinase inhibitor ZDI839 is generally well-tolerated and has activity in non-small-cell lung cancer and other solid tumors: results of a phase I trial. I Clin Oncol 2002, 20:38I5-3825.

9. Nakagawa K, Tamura T, Negoro S, Kudoh S, Yamamoto N, Yamamoto N, Takeda K, Swaisland H, Nakatani I, Hirose M, Dong RP, Fukuoka M: Phase I pharmacokinetic trial of the selective oral epidermal growth factor receptor tyrosine kinase inhibitor gefitinib ('Iressa', ZDI839) in Japanese patients with solid malignant tumors. Ann Oncol 2003, 14:922-930.

10. Fukuoka M, Yano S, Giaccone G, Tamura T, Nakagawa K, Douillard JY, Nishiwaki Y, Vansteenkiste J, Kudoh S, Rischin D, Eek R, Horai T, Noda K, Takata I, Smit E, Averbuch S, Macleod A, Feyereislova A, Dong RP, Baselga J: Multi-institutional randomized phase II trial of gefitinib for previously treated patients with advanced non-small-cell lung cancer. J Clin Oncol 2003, 21 1:2237-2246.

II. Kris MG, Natale RB, Herbst RS, Lynch TJ Jr, Prager D, Belani CP, Schiller JH, Kelly K, Spiridonidis H, Sandler A, Albain KS, Cella D, Wolf MK, Averbuch SD, Ochs JJ, Kay AC: Efficacy of gefitinib, an inhibitor of the epidermal growth factor receptor tyrosine kinase, in symptomatic patients with non-small cell lung cancer: a randomized trial. JAMA 2003, 290:2।49-2।58.

12. Inoue A, Saijo Y, Maemondo M, Gomi K, Tokue Y, Kimura Y, Ebina M, Kikuchi T, Moriya T, Nukiwa T: Severe acute interstitial pneumonia and gefitinib. Lancet 2003, 36 I: 137-139.

13. Nishimura T, Tada H, Nakagawa M, Teramukai S, Matsui S, Fukushima $M$ : Lessons from gefitinib-induced interstitial lung disease in Japan: Problems in approval, pharmacovigilance, and regulatory decision-making procedures. Pharmacy Practice 2006 , 4:168-178 [http://www.pharmacypractice.org/vol04/pdf//68-178en.pdf].

14. Mountain CF: Revisions in the international system for staging lung cancer. Chest 1997, II I:1710-1717.

15. Bahri P, Tsintis P: Pharmacovigilance-related topics at the level of the International Conference on Harmonisation (ICH). Pharmacoepidemiology and Drug Safety 2005, 14:377-387.

16. Therasse P, Arbuck SG, Eisenhauer EA, Wanders J, Kaplan RS, Rubinstein L, Verweij J, Van Glabbeke M, van Oosterom AT, Christian MC, Gwyther SG: New guidelines to evaluate the response to treatment in solid tumors. J Natl Cancer Inst 2000, 92:205-216.

17. Miller $A B$, Hoogstraten $B$, Staquet $M$, Winkler $A$ : Reporting results of cancer treatment. Cancer 198I, 47:207-214.

18. Kaneda H, Tamura K, Kurata T, Uejima H, Nakagawa K, Fukuoka M: Retrospective analysis of the predictive factors associated with the response and survival benefit of gefitinib in patients with advanced non-small-cell lung cancer. Lung Cancer 2004, 46:247-54.

19. Maruyama R, Nishiwaki Y, Tamura T, Yamamoto N, Tsuboi M, Nakagawa K, Shinkai T, Negoro S, Imamura F, Eguchi K, Takeda K, Inoue A, Tomii K, Harada M, Masuda N, Jiang H, Itoh Y, Ichinose Y, Saijo N, Fukuoka M: Phase III study, V-15-32, of gefitinib versus docetaxel in previously treated Japanese patients with nonsmall-cell lung cancer. J Clin Oncol 2008, 26:4244-4252.

20. Takano T, Ohe $Y$, Kusumoto M, Tateishi U, Yamamoto S, Nokihara H, Yamamoto N, Sekine I, Kunitoh H, Tamura T, Kodama T, Saijo N: Risk factors for interstitial lung disease and predictive factors for tumor response in patients with advanced non-small cell lung cancer treated with gefitinib. Lung Cancer 2004, 45:93-104.

21. Hotta K, Kiura K, Tabata M, Harita S, Gemba K, Yonei T, Bessho A, Maeda T, Moritaka T, Shibayama T, Matsuo K, Kato K, Kanehiro A, Tanimoto Y, Matsuo K, Ueoka H, Tanimoto M: Interstitial lung disease in Japanese patients with non-small cell lung cancer receiving gefitinib: an analysis of risk factors and treatment 
outcomes in Okayama Lung Cancer Study Group. Cancer J 2005, I I:4I7-424.

22. Yoshida S: The results of Gefitinib Prospective Investigation. Medicine and Drug Journal 2005, 4I:772-789.

23. Ando M, Okamoto I, Yamamoto N, Takeda K, Tamura K, Seto T, Ariyoshi $Y$, Fukuoka M: Predictive factors for interstitial lung disease, antitumor response, and survival in non-small-cell lung cancer patients treated with gefitinib. J Clin Oncol 2006, 24:2549-2556

24. Kudoh S, Kato H, Nishiwaki Y, Fukuoka M, Nakata K, Ichinose Y, Tsuboi M, Yokota S, Nakagawa K, Suga M, Japan Thoracic Radiology Group, Jiang H, Itoh Y, Armour A, Watkins C, Higenbottam T, Nyberg F: Interstitial lung disease in Japanese patients with lung cancer: a cohort and nested case-control study. Am J Respir Crit Care Med 2008, 177:1348-1357.

Publish with Biomed Central and every scientist can read your work free of charge

"BioMed Central will be the most significant development for disseminating the results of biomedical research in our lifetime. "

Sir Paul Nurse, Cancer Research UK

Your research papers will be:

- available free of charge to the entire biomedical community

- peer reviewed and published immediately upon acceptance

- cited in PubMed and archived on PubMed Central

- yours - you keep the copyright

Submit your manuscript here:

http://www.biomedcentral.com/info/publishing_adv.asp 